Reprinted from Aronves of Brochemistar ann Biopiraick Volume 105, No. 3, June, 1964

Copyright (C) 1964 by Academic Press Inc.

\title{
The Identification of New Histamine Derivatives in the Skin of Leptodactylus'
}

\author{
V. FRSPAMER, T. VITAII AND M. ROSEGHINI \\ From the Institutes of Pharmacology and Pharmaceutical Chemistry of the University \\ of Parma, Parma, Italy \\ AND J. M. CEI \\ From the Institute of Biology, National University of Cuyo, Mendoza, Argentina \\ Received November 18, 1963
}

\begin{abstract}
Extracts of the skin of some South American amphibians belonging to the genus Leptodactylus contain, in addition to 5-hydroxyindolealkylamines and hydroxyphenylalkylamines, remarkable amounts of imidazolealkylamines. The species most rich in these compounds are Leptodactylus pentadactylus labyrinthicus and Leptodactylus laticeps. The skin of the former species contains not only histamine, $N^{\prime}$-methylhistamine and $N^{\prime}, N^{\prime}$-dimethylhistamine but also two imidazo-c-pyridine derivatives hitherto unknown in nature: spinaceamine and 6-methylspinaceamine. The new findings permit a notable enlargement of our knowledge in the field of biogenic imidazolealkylamines and illustrate new possible metabolic pathways for histamine.
\end{abstract}

During a systematic investigation on biogenic amines and active polypeptides in the amphibian skin it was found that acetone extracts of the skin of Leptodactylus pentadactylus labyrinthicus, besides containing small amounts of leptodactyline (1) and considerable amounts of 5-hydroxytryptamine (5-HT), also contained large amounts of imidazole derivatives. Imidazole compounds were also found in Leptodactylus laticeps and, to a much lesser extent, in Leptodactylus pentadactylus dengleri and Leptodactylus pentadactylus pentadactylus.

The present communication describes the techniques which were applied for the identification and the quantitative estimation of five of the imidazole derivatives present in the skin extracts and gives a tentative schematic representation of the

I This work was supported by grants from the Consiglio Nazionale delle Ricerche, Roma, and the Rockefeller Foundation, New York. biochemical correlations existing among the different compounds. A preliminary report on this topic has already appeared (2).

\section{MATERIALS AND METHODS}

The amphibian material considered in this study was as follows:

(1) Leptodactylus pentadactylus labyrinthicus: 7 adult specimens (weight of the dry skins $=73$ g.) captured in Misiones, Argentina, in February, 1961 and 5 adult specimens (dry skins $=32$ g.) captured at the same place in September, 1961.

(2) Leptodactylus pentadactylus pentadactylus: $\overline{5}$ adult male specimens (dry skins $=51.9$ g.) captured at Iquitos, Peruvian Amazonia, in September, 1962.

(3) Leptodactylus pentadactylus dengleri: 1 adult specimen (dry skin $=5.4$ g.) captured in Costa Rica in May, 1962.

(4) Leptodactylus laticeps: 1 adult female specimen (dry skin $=5.6$ g.) captured in Misiones in February, 1961.

The fresh skins were carefully spread out 
and dried in the shade. Inmediately after their arrival in Italy by air mail they were minced with scissors and then immersed in 8 parts $(\mathrm{w} / \mathrm{v})$ of $70 \%$ acetone. The licuuid was decanted after a week, and the skins were extracted for another week with 5 - 6 parts of the solvent. The acetone extracts, brown yellow in color, were combined and filtered. Kept in dark bottles and refrigrrated, they may be stored for months without appreciable loss of biogenic amines.

Alkaline alumina was a chromatographic grade product obtained from Merck A.C., Darmstadt. ('hromatographic columns were of different size according to the amount of the material to be chromatographed. For amounts excecding $20 \mathrm{~g}$. of dry skin, the columms were $3.3 \mathrm{~cm}$. wide and $50 \mathrm{~cm}$. high and the alumina weighed $140 \mathrm{~g}$.

The ascending unidimonsional technicue on Whatman No. 1 paper was routincly cmployed. (hromatograns were run at $18^{\circ} \mathrm{C}$. for 20-30 hours. The following solvents were used: $n$-butanol-30\% mothylamine $(80: 30)$; 1-pentanol-pyridine-water$30 \%$ methylamine (40:40:10:1); benzyl alcohol-n-butanol-30\% methylamine (30: $.50: 30)$; ethanol - ethyl cther - water - 30 '; methylanine (40:50:10:0.5); methylethyllictone - pyridine - water - 30\% methylanine (6i):15:10:0.5); isopropanol-0.2.$M$ ammonia (30:10); $n$-butanol-pyridine-wate $(60: 30: 10) ; n$-butanol-acetic acid-water $(40$ : $10: 50)$; $n$-butanol-ethanol-acotic acid-water $(80: 20: 10: 30)$.

Paper chromatograns were sprayed with the following devcloping reagents: (a) acqueous solution of diazotized sulfanilie acid (l'auly reagent) followed by $35 \%$ arfueous sodium carbonate; (b) acpueous solution of diazotized $p$-nitroaniline, followed by sodium carbonate; (c) $0.0 .5-0.1 \%$ aleoholic solution of dichloroguinone chlorinide (( iibbs reagent) followed by sodiun carbonate; (d) 1-2\% aleoholic solution of $p$-dimethylaminobenzaldehyde, followed by exposure of the chromatograms to HCI vapours in a glass cabinet; (e) $0.2-0.4 \%$ solution of Heimrich and schuler XXCI) reagent (2 - chloro - 4 - nitro - 1 - diazobenzene - $\alpha$ naphthalene sulfuric acid) in $0.1 M \mathrm{HCl}$; (f) ciluted Folin-Ciocalten reagent, followed by sodium carbonate or exposure to annmonia vapours; (g) $1 \%$ alcoholic solution of Folin reagent for aminoacids (1,2-naphtoquinone-4-sulfonic sodium salt) followed by sodium carbonate. All the solvents and reagents were of the analytical grade.

Inidazole derivatives are characterized by the positivity of reactions (a), (b), and eventually (g), as well as by the negativity of all other reactions; phenolic derivatives by the positivity of reactions (a), (b), (f), and eventually (c) and (g); i-hydroxyindole compounds by the positivity of all the tested reactions.

Semiquantitative estimation of imidazoles on paper chromatograms was carried out by visual comparison of the inidazole spots produced by different amounts of erude or purified skin extracts with the spots produced by different known anounts of the corresponding pure synthetic compounds.

Quantitative colorimetric estimation of the inidazole compounds diretly in extracts and eluates was performed with the l'auly-Mepherson's method as modified by Porath (3). "Two-tenths ml. of a $1 \%$ solution of sulfanilic acid in $10 \% \mathrm{H}$ ('l and $0.2 \mathrm{ml}$. of a $5 \%$ acpueous solution of sodium nitrite are added to $0.1 \mathrm{ml}$. of a suitably concentrated cluate or extract previously brought to $\mathrm{pH}$ (6.5 with $M I$ HCl. The mixture is shaken for 12 minutes and then allowed to stand in the refrigerator for 30 minutes, after which $0.5 \mathrm{ml}$ of $20 \%$ sodium carbonate and $5 \mathrm{ml}$. of $50 \%$ ethanol containing $0.2 \%$ sodium carbonate are added. The developing pink or orange red color is read in a Beckman spectrophotometer at 490 and $420 \mathrm{~m} \mu$, respectively.

The isolated guinea-pig ileum suspended in $10 \mathrm{ml}$. of Krebs solution containing $10^{-\bar{T}}$ atropine and $10^{-7}$ 2-bromolysergic acid diethylanide (BOL) was the smooth muscle preparation generally used in the qualitative and quantitative bioassay of inidazolealkylanines.

The following imidazole compounds were synthetized in our laboratory: $N^{\prime}$-methylhistanine.2 HCl (0.63); $N^{\prime}, N^{\prime}$-dimethylhistamine.2 HCl $(0.66)$; 4-imidazolecthyltrimethylammonium $(\mathrm{y}) \cdot \mathrm{H}(\mathrm{l} \quad(0.76) ; 4,5,-$ 6,7-tetrahydroinidazo $[\overline{5}, 4-c]$ pyridine. 2 
$\left.\mathrm{HCl} \cdot \mathrm{H}_{2} \mathrm{O}\right)(0.57) ; \quad 6$-methyl-4,5),6,7-tetrahydroimidazo $[5,4-c]$ pyridine $\cdot 2 \mathrm{HCl}(0.65)$; and $4,5,6,7$-tetrahydroimidazo $[5,4-c]$ pyridine-5)-carboxylic acid or spinacine. In parentheses are the equivalnets in free bases. The name spinaceamine has been suggested (see Discussion) for $4,5,6,7$ tetrahydroimidazo $[5,4-c]$ pyridine, and that of 6-methylspinaceamine for its 6 methyl derivative.

A complete description of the niethods of synthesis and characterization of the alove compounds is given in another paper (4). As spinacine is concerned see also Ackermann and Skraup (5)). Our synthetic spinacine and spinaceamine were indistinguishable from samples of the same compounds kindly supplied by Irofessor I). Ackermann, Würzburg, (iermany.

L-Histidine and histamine dihydrochloride (0.60) were purchased from I Ioffmann-La Roche, Basle, Switzerland.

\section{EXPERIMENTAL}

\section{Adsorption on Allialine Alumina}

In a typical experiment, $400 \mathrm{ml}$. of the Leptodactylus pentadactylus labyrinthicus September, 1961 extract, corresponding to $30 \mathrm{~g}$. dry skin, was evaporated under reduced pressure and at $45-500^{\circ} \mathrm{C}$, to $40-50 \mathrm{ml}$., and the remaining aqueous liquid was extracted repeatedly with petroleum ether in order to remove fats. The distillation was then continued until the residue was of syrupy consistence. The residue was taken up in a warm water bath, by stirring in $100 \mathrm{mI}$. of $99 \%$ ethanol and the liquid was passed through a colunn of alkaline alunina. Iitution of the column was effected with sucesssive addition of $400 \mathrm{ml}$. cach of 99 and $95 \%$ ethanol, 200 ml. each of $90,80,70,60,50,40$, and $30 \%$ ethanol, and $200 \mathrm{ml}$. of distilled water. l'ractions of $200 \mathrm{~m}$ l. were collected.

\section{Paper Chromatography-Color Reactions}

Aljquots of the above eluates were suitably concentrated under reduced pressure (1 $\mathrm{ml}$ l. liquid $=2-5 \mathrm{~g}$. dry skin) and then chromatographed on paper. Figures 1 and 2 give a schematic representation of the imidazole spots developed by the Pauly reagent on chromatograms run with the $n$-butanol- acetic acid-water and the $n$-butanol-methylanine mixtures, respectively. 'The main inidazole spots are indicated by Roman numerals, the minor spots by Arabic numerals.

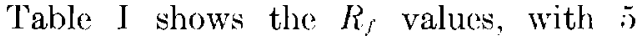
different solvent systems, of the Paulypositive spots and rable II the color reactions produced by 3 different reagents. 'To permit immediate comparison, the Tables also show $R_{f}$ values and color reactions of a number of synthetic inidazole compounds.

In addition to the solvents listed in 'Table I, several other solvents were tried with no advantage or with complete failure. Acid solvents, for example, were soon ahandoned owing to the slight mobility of the inidazole compounds, and because synthetic hydrochlorides often gave double spots, irregular in their size. Alkaline solvents proved to be far more satisfactory and have been routinely used.

It clearly appears from the tabulated data that substances making up spots I, III, IV, V, VI and VII are indistinguishable looth by $R_{f}$ values and color reactions from (j-methylspinaceanine, $N, N$-dimethylhistamine, spinaceanine, $N$-methyl-histanine, histamine, and histidine, respectively.

This is true even for the solvent mixtures not reported in Table I. In no instance was there any disaceordanee between the $R_{f}$ values of a natural inidazole derivative and the comesponding synthetic compound and in superimposition experiments the single natural and synthetic compounds gave always single spots. (If course, both natural and synthetic inidazole compounds did not present any color reaction on spraying with the $p$-dimethylaminobenzaldehyde, the XNCI) and the Folin-(Yiocalteu reagents.

The identification of the substance making up spot II is in progress. Although this substance has already been prepared by synthesis, his structure has not been fully elucidated till now. The possibility camnot. be ruled out that some of the minor spots are artifacts, constituted by alteration products appearing during drying of the skin, or during preparation or chromatography of the extraets.

It may be seen from Table I that the 


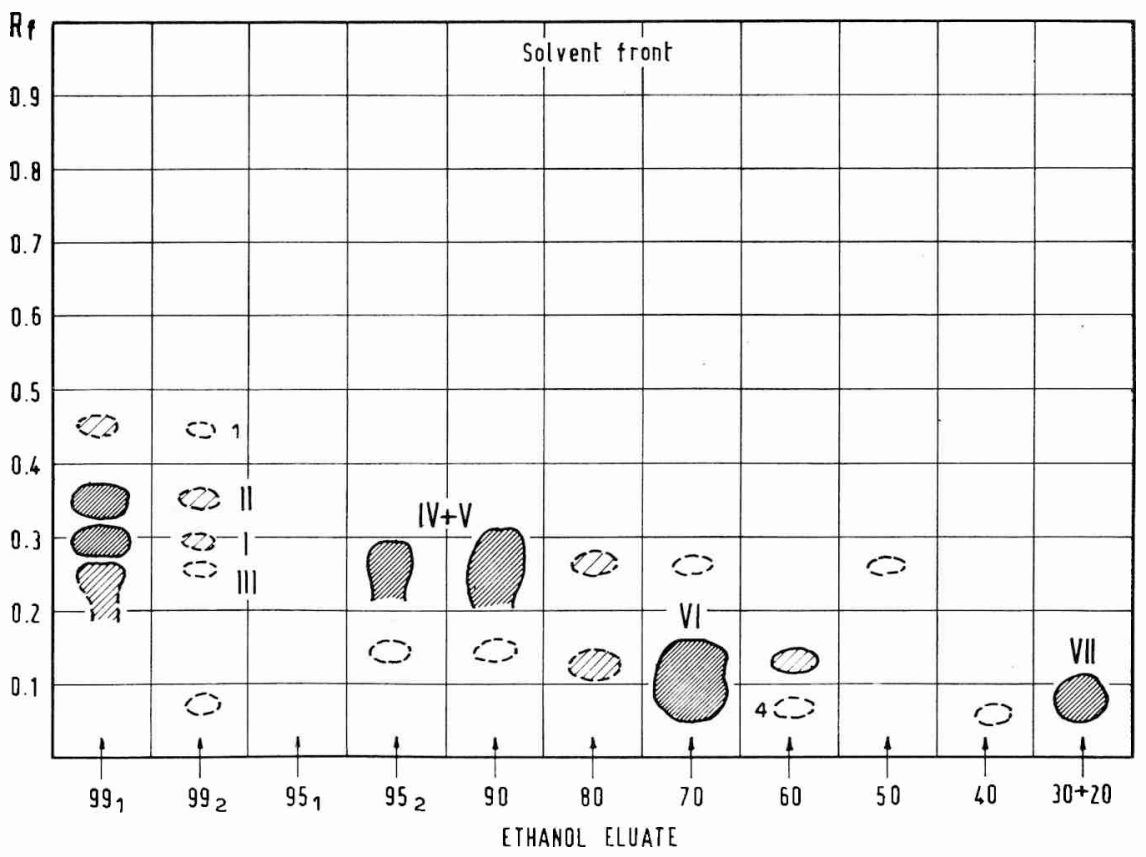

Fici. 1. Paper chromatograms of the ethanol eluates obtained from an alumina column loaded with the skin extract of Leptodactylus pentadactylus labyrinthicus Sept., 1961. Solvent, $n$-butanol-acetic acid-water; developing reagent, diazotized sulfanilic acid + sodium carbonate. Amounts of eluates corresponding to $0.1 \mathrm{~g}$. of dry skin were applied on paper at arrows.

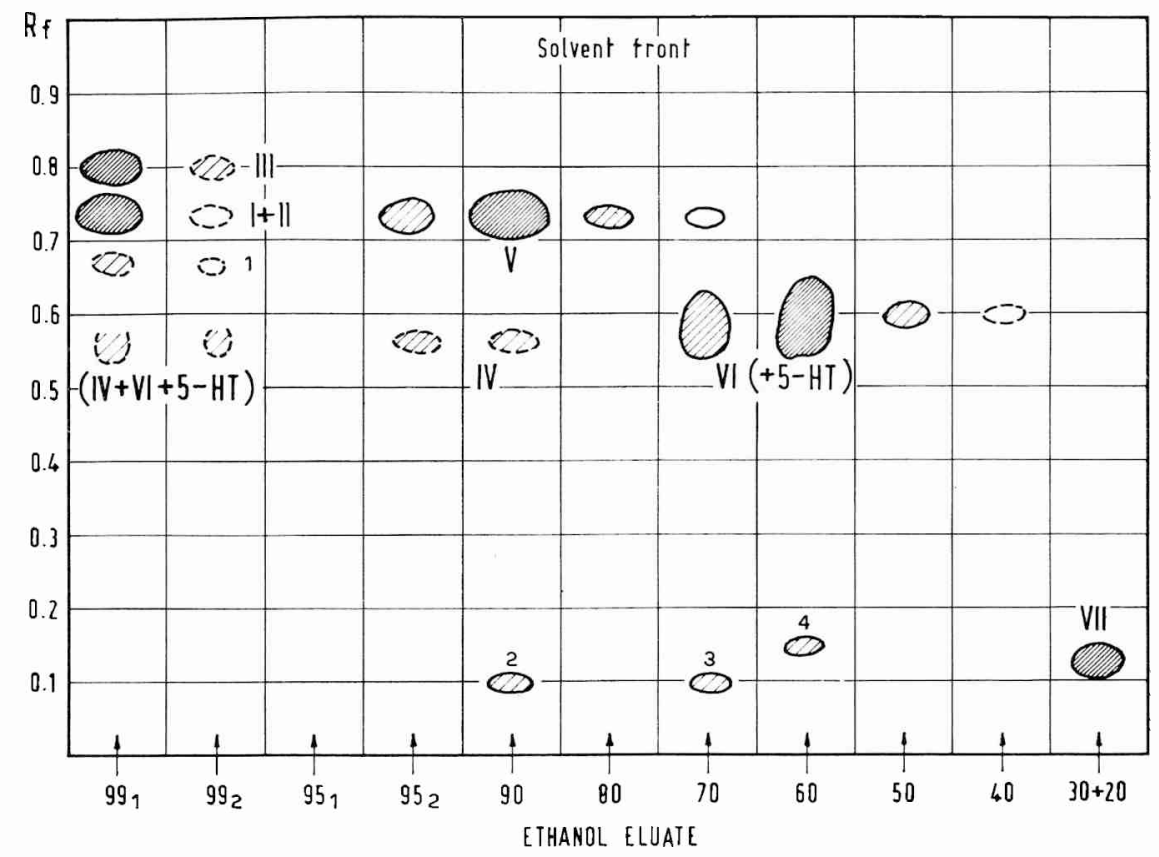

Fia. 2. Paper chromatograms as described in the text of Fig. 1., using as solvent the $n$-butanolmethylamine mixture. 
TABIA' I

$R_{f}$ Valves of Natural and Synthetic: Imidazole Derivatives with Different Solavents.

\begin{tabular}{|c|c|c|c|c|c|}
\hline & $\begin{array}{l}n \text {-Butanol }+ \\
\text { methylamine }\end{array}$ & $\begin{array}{c}\text { 1-Pentanol }+ \\
\text { pyridine }+ \\
\text { water }+ \text { meth- } \\
\text { ylamine }\end{array}$ & $\begin{array}{l}\text { Isopropanol } \\
+\mathrm{NH}\end{array}$ & $\begin{array}{l}\text { Methylethyl- } \\
\text { ketone }+ \\
\text { pyridine }+ \\
\text { water }+ \text { meth- } \\
\text { ylamine }\end{array}$ & $\begin{array}{l}n \text {-Butanol + acetic } \\
\text { acid }+ \text { water }\end{array}$ \\
\hline Spot I & $0.73-0.78$ & $0.59-0.61$ & $0.75-0.86$ & $0.52-0.55$ & $0.28-0.30$ \\
\hline 6-Methylspinaceamine & $0.78-0.79$ & $0.60-0.64$ & $0.81-0.82$ & $0.49-0.52$ & double spot \\
\hline Spot II & $0.79-0.80$ & $0.65-0.66$ & $0.75-0.80$ & $0.5(i-0.62$ & $0.35-0.37$ \\
\hline Spot III & 0.80 & $0.68-0.70$ & $0.83-0.86$ & $0.66-0.72$ & $0.24-0.26$ \\
\hline$X, N$-Dimethylhistamine & $0.82-0.86$ & $0.69-0.74$ & $0.85-0.88$ & $0.66(6-0.69$ & double spot. \\
\hline Spot IV & $0.54-0.59$ & 0.38 & $0.63-0.66$ & $0.25-0.26$ & $0.13-0.16$ \\
\hline Spinaceamine & $0.60-0.62$ & 0.37 & $0.67-0.69$ & $0.24-0.26$ & double spot \\
\hline Spot V & $0.72-0.74$ & $0.54-0.55$ & $0.73-0.78$ & $0.49-0.51$ & $0.23-0.25$ \\
\hline$\lambda$-Methylhistamine & $0.74-0.76$ & $0.53-0.56$ & $0.78-0.82$ & $0.48-0.51$ & double spot \\
\hline Spot VI & $0.55-0.58$ & $0.35-0.37$ & $0.60-0.65$ & $0.55-0.60$ & $0.11-0.13$ \\
\hline Histamine & $0.59-0.61$ & $0.36-0.38$ & $0.63-0.67$ & $0.54-0.57$ & double spot \\
\hline Spot VII & 0.16 & - & 0.41 & $0.15-0.20$ & $0.07-0.10$ \\
\hline Histidine & $0.15-0.16$ & - & 0.43 & $0.15-0.20$ & $0.07-0.10$ \\
\hline Spot 1 & $0.64-0.69$ & 0.30 & -- & & $0.45-0.46$ \\
\hline Spot 2 & $0.09-0.10$ & - & $\cdots-$ & - & 0.10 \\
\hline Spot 3 & 0.11 & - & $\cdots-$ & - & \\
\hline Spot 4 & 0.16 & $\cdots$ & - & $\ldots$ & \\
\hline $\begin{array}{l}\text { 4-Imidazoleethyltrimethyl- } \\
\text { ammonium }\end{array}$ & 0.09 & 0.04 & $0.25-0.29$ & $0.03-0.01$ & double spot \\
\hline Spinacine & $0.19-0.21$ & & 0.45 & $0.12-0.15$ & $0.10-0.12$ \\
\hline
\end{tabular}

TABI,I; II

Color Reactons of Naturat and Syetuetic: IMidazole Dehivatives

Numbers in brackets represent the threshold dose (in $\mu \mathrm{g}$.) necessary for an appreciable reaction on paper.

\begin{tabular}{|c|c|c|c|}
\hline & $\begin{array}{c}\text { Diazotized sulfanilic acid }+ \\
\text { sodium carbonate }\end{array}$ & $\begin{array}{l}\text { Diazotized p-nitrouniline }+ \\
\text { sodium carbonate }\end{array}$ & Folin redgent \\
\hline Spot I & $\begin{array}{l}\text { Orange yellow turning } \\
\text { into orange red }\end{array}$ & Light brown & Gimerald green \\
\hline (i-Methylspinaceanine & $\begin{array}{l}\text { Orange yellow turning } \\
\text { into orange red [2] }\end{array}$ & Ijight brown $[2-3]$ & Limerald green $|5-10|$ \\
\hline Spot II & Pink red & Brownish violet & Light blue \\
\hline Spot III & Pink red & Brownish violet & ? (Pale pink) \\
\hline$N, N$-I Dimethylhistamine & Pink red $[<1]$ & Brownish violet $[1]$ & ? (Pale pink) $\lfloor 20-30]$ \\
\hline Spot IV & $\begin{array}{l}\text { Orange yellow turning } \\
\text { into orange red }\end{array}$ & Brownish violet & Rose \\
\hline Spinaceamine & $\begin{array}{l}\text { Orange yellow turning } \\
\text { into orange red [2] }\end{array}$ & Brownish violet [2-3] & liose $[4-0]$ \\
\hline Spot V & Pink red & Brownish (rose) & Rose \\
\hline$N$-Methylhistamine & Pink red $[<1]$ & Brownish (rose) $[<1]$ & Rose $[5]$ \\
\hline Spot VI & Pink red & Brownish violet & Gray blue \\
\hline Histamine & Pink red $[<1]$ & Brownish violet $[1]$ & Gray blue [2] \\
\hline Spot VII & Pink red & Brownish violet & Brown \\
\hline Histidine & Pink red $[<1]$ & Brownish violet $[1]$ & Brown [2-3] \\
\hline Spot 1 & Pink red & $\cdots-$ & - \\
\hline Spot 2 & Pink red & - & - \\
\hline Spot 3 & Pink red & $\ldots$ & - \\
\hline Spot 4 & Pink red & - & - \\
\hline $\begin{array}{l}\text { 4-Imidazoleethyltri- } \\
\text { methylammonium }\end{array}$ & Pink red [1] & Brownish violet [1-2] & ? (Pale pink) $[50-100]$ \\
\hline Spinacine & $\begin{array}{l}\text { Orange yellow turning } \\
\text { into orange red [2] }\end{array}$ & - & Brownish $[10-15]$ \\
\hline
\end{tabular}


inidazole compounds which are more difficult to distinguish by paper chromatography are represented by $N$-methylhistamine and 6-methylspinaceamine, and by histamine and spinaceamine, respectively. However, histanine may be distinctly separated from spinaceanine by the methyl(thylketone solvent and, on the other hand, a sharp distinction between $N$-methylhistamine and 6-methylspinaceamine, the two noarest compounds in their $R_{j}$ values in all the tested solvents, is made easy by the lolin reaction, pink for $N$-nethylhistamine and emerald green for 6-methylspinaceanine. The sane reaction is also useful in distinguishing between the other inidazole compounds. From experiments we have carried out on numerous inidazole-, indole-, and phenyl-alkylanines it seents that primary anines as a rule give bluish or grey-blue eolol's, sccondary amines pink shades, and tertiary anines as well as (quaternary ammonium bases only slowly developing faint colors or no color reaction at all.

Histamine, $N$-methylhistamine, and $N, N$ dimethylhistanine behave in their adsorption on alumina exactly like the conresponding 5 -hydroxyindolealkylamines. In fact, bufotenine is not adsorbed, like $N, N$ dimethylhistanine, by alumina and henec appears in the first eluate; 5 -H'T is eluted, like histamine, by $80-70 \%$ ethanol; and $N$-nethyl-5)-H' is eluted, again like $N$ methylhistanine, by an intermediate ethanol concentration.

Iigures 1 and 3 show that alumina column allows a clear-cut separation of four groups of imidazole derivatives: $N, N$-dinethylhistamine +6 -methylspinaceamine + comlpound II; $N$-methylhistamine + spinaceamine; histamine; histidine. Thus, the successive use of alumina chromatography and paper chromatography allows a fully satisfactory distinction among the different imidazole derivatives considered in this study.

\section{Pharmacological Actions}

Hiluates $99_{1}, 90$, and 70 were separately chromatographed on paper using the $n$ butanol-nethylanine mixture as solvent,

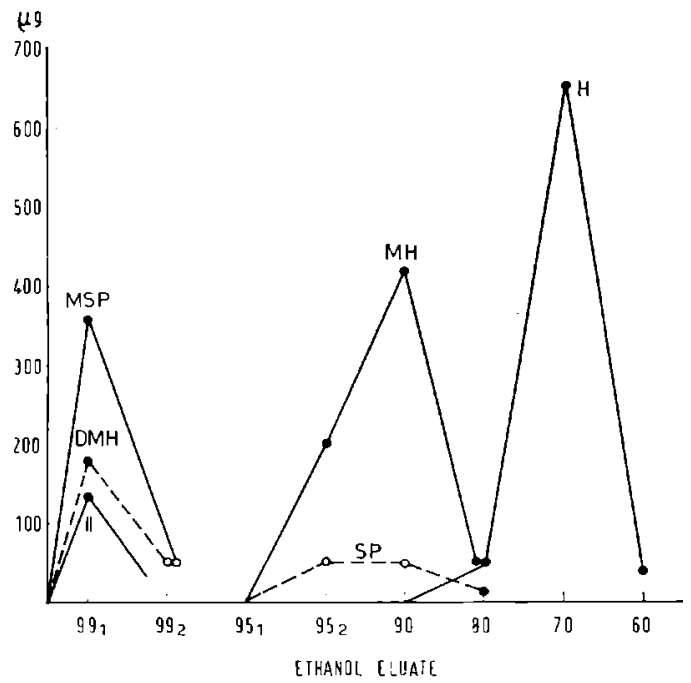

I'I $\mathrm{x}$. 3. Recovery of imidazolealkylamines (in $\mu \mathrm{g}$. per $\mathrm{g}$. dry skin of Leptodactylus pentadactylus labyrinthicus Sept., 1961) in the ethanol eluates of all alumina column. (j-Methylspinaceanine (MSP), $\mathrm{N}, \mathrm{V}$-dimethylhistamine (I)MH) and compound II (II) were not adsorbed by the column, spinaceamine (SP) and $N$-methylhistamine (MH) were eluted by 95 and $90 \%$ ethanol, histamine $(\mathrm{H})$ by $70 \%$ ethanol.

and spots I + II, III, IV, V, and VI were separately eluted with Krebs solution. Spot II was also eluted from chromatograms run with $n$-butanol-acetic acid-water. The cluates were assayed on the guinea-pig ilcum. It was shown that:

(a) Hiluates of spots III, V, and VI displayed a powerful stinulant action which was completely blocked by mepyramine $10^{-7}$. lior spots giving a Pauly reaction of the same intensity, biological activity was maximum $(100 \%)$ for spot VI, $60-80 \%$ for spot $V$, and approximately $30 \%$ for spot III. This corresponds satisfactorily to the activity ratios existing between histamine and $N$-methylhistamine, and between histamine and $N, N$-dimethylhistamine, respectively.

(b) Hiluates of spots I, II and IV were virtually inactive, like synthetic spinaceamines'.

Thus, bioassay offers strong additional

"Eertaceini, ( $i$, and Vitali, T., unpublished data. 
TABLE III

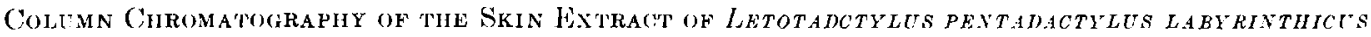
Sept., $1961^{a}$

\begin{tabular}{|c|c|c|c|c|c|c|c|c|c|}
\hline \multirow{2}{*}{ Imidazole compound } & \multicolumn{9}{|c|}{ Imidazolealkylamine content (in $\mu$ g. free bases per $\mathrm{g}$. dry skin) in ethanol eluates } \\
\hline & 99, & $99_{2}$ & 951 & 9.52 & 90 & 80 & 70 & 60 & Total \\
\hline \\
\hline \multicolumn{10}{|l|}{ 6-Methylspinaceamine } \\
\hline p.ch. & $350-375$ & 50 & $0^{b}$ & 0 & 0 & 0 & 0 & 0 & $400-425$ \\
\hline sp.m. & 330 & - & - & - & - & - & - & - & - \\
\hline \multicolumn{10}{|l|}{ Compound II } \\
\hline p.ch. & $125-150$ & 10 & 0 & 0 & 0 & 0 & 0 & 0 & $135-160$ \\
\hline \multicolumn{10}{|l|}{$N, \Lambda$-Dimethylhistamine } \\
\hline p.ch. & $170-190$ & $40-50$ & 0 & 0 & 0 & 0 & 0 & 0 & $210-240$ \\
\hline sp.m. & 150 & - & - & - & - & - & - & - & - \\
\hline b. & 160 & - & - & - & - & - & - & - & - \\
\hline \multicolumn{10}{|l|}{ Spinaceamine } \\
\hline p.ch. & 10 & $1-2$ & 0 & 50 & 50 & 10 & 1 & 0 & 120 \\
\hline \multicolumn{10}{|l|}{$N$-Methylhistamine } \\
\hline p.ch. & 0 & 0 & 0 & 200 & 420 & 50 & 0 & 0 & 670 \\
\hline sp.m. & - & - & 一 & - & 370 & - & - & - & - \\
\hline b. & - & - & - & 180 & 350 & - & - & - & - \\
\hline \multicolumn{10}{|l|}{ Histamine } \\
\hline p.ch. & $15-20$ & 0 & 0 & 0 & 0 & 50 & 650 & 40 & 740 \\
\hline sp.m. & - & - & - & - & - & - & 550 & - & - \\
\hline b. & - & - & - & - & - & 50 & 500 & 35 & - \\
\hline
\end{tabular}

"The inidazolealkylamine content of the ethanol eluates, as determined by paper-chromatography (p.eh.), Pauly-Porath spectrophotometric method (sp.m.), and bioassay (b.).

${ }^{b} 0$, not detectable; - not estimated.

support in favor of the previously suggested identification of the imidazole compounds in the Leptodactylus skin.

\section{Quantitative Estimation of the \\ Imidazolealkylamine content of the Isptodactylus Skin}

This was carried out chiefly by visual comparison of imidazole spots produced on paper chromatograms by the different ethanol eluates with spots produced by known amounts of the corresponding synthetic imidazole compounds. When possible, semi-quantitative paper chromatographic estimation was checked and completed by spectrophotometric estimation and by bioassay.

Results are shown in Table III and in Fig. 3. It may be seen that values obtained with different methods are in fairly good accordance, although values given by the semiquantitative paper chromatographic method are always somewhat higher than those given by the two other more accurate methods.

The content of imidazolealkylamines in cluates of Leptodactylus pentadactylus labyrinthicus February, 1961 and of other strictly related sub-species and species is shown in Table IV.

It is evident that there are striking quantitative and qualitative differences in the imidazolealkylamine content of the different Leptodactylus pentadactylus subspecies and that conspicuous quantitative differences may be found even among different batches of Leptodactylus pentadactylus labyrinthicus. Leptodactylus laticeps appears to be particularly rich in compound II. 
TABLE IV

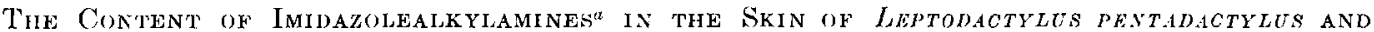
LEPTODACTYLUS LATICEPS AS DETERMINEI) BY VISIAAL, (OMPARISON OF Chromatographic: Spot's

\begin{tabular}{lccccc}
\hline & Elistamine & $\begin{array}{c}\text { N-Methyl- } \\
\text { histamine }\end{array}$ & $\begin{array}{c}\text { N,N-1)imethyl- } \\
\text { histamine }\end{array}$ & Spinaceamine & $\begin{array}{c}6-\text { Methy!- } \\
\text { spinaceamine }\end{array}$ \\
Lept. pentad. labyrinthicus & & & & & \\
February, 1961 & 100 & $100-120$ & $30-40$ & 20 & $25-30$ \\
September, 1961 & 740 & 670 & $210-240$ & 120 & $400-425$ \\
Lept. pentad. pentadactylus & $10-20$ & n.d. & n.d. & n.d. & n.d. \\
Lept. pentad. dengleri & 35 & n.d. & n.d. & n.d. & n.d. \\
Lept. laticeps & $260-280$ & n.d. & n.d. & $5-10(?)$ & n.d. \\
\hline
\end{tabular}

"In $\mu \mathrm{g}$. free bases per g. dry tissue.

"n.d. = not detectable $(<1-2 \mu \mathrm{g} . / \mathrm{g}$. $)$.

TABLE, V

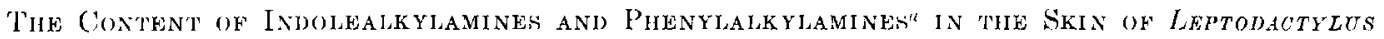
PEYTADACTYLUS ANI LEPTODACTYLUS LATITEPS

\begin{tabular}{|c|c|c|c|c|}
\hline & \multicolumn{2}{|c|}{ Indolealkylamines } & \multicolumn{2}{|c|}{ Phenylalkylamines } \\
\hline & $5-\mathrm{HT}$ & Bufotenidine & Leptodactyline & Candicine \\
\hline \multicolumn{5}{|l|}{ Lept. pentadactylus labyrinthicus } \\
\hline February, 1961 & 200 & n.d. & $1.3-1.8$ & n.d. \\
\hline September, 1961 & $1800-2000$ & n.d. & 12.5 & n.d. \\
\hline Lept pentadactylus pentadactylus & $130-150$ & n.d. & 9 & $40-50$ \\
\hline Lept. pentadactylus dengleri & $50-(65$ & 600 & $11-13$ & $2-3(?)$ \\
\hline Lept. laticeps & 280 & n.cl. & $2.2-3$ & n.d. \\
\hline
\end{tabular}

"In $\mu$ g. free base per g. dry tissue.

bixpressed as 5-H'T.

"n.d. = not detectable $(<1-2 \mu \mathrm{g} . / \mathrm{g}$. $)$.

No detectable amounts of imidazolealliy lamines could be found in skin extracts of Leptodactylus ocellatus, $I$. chaquensis, $L$. podicipinus podicipinus, L. podicipinus petersi, L. rubido cope, L. melanonotus, $L$. prognatus and $L$. bufonius.

Data reported in Table $V$ will help to give a nore complete idea about all the biologie amines occurring in the skin of $L$. pentadactylus and $L$. laticeps. They will be discuseed in detail in other papers.

\section{I) ISTCTSAION}

Results obtained in the present study have substantially enlarged our knowledge in the field of biogenic inidazolealkylamines. In fact, it has been demonstrated that amphibian skin, which is a vertebrate tissue, may contain the following inidazole derivatives: histamine; $N$-methylhistamine; $N, N$-di- methylhistamine; $4,5,6,7$ - tetrahydioimidazo [5,4-c] pyridine; 6-methyl-4,5, 6,7-tetrahydroinidazo $[\bar{i}, 4-c]$ pyridine; histidine.

Leaving aside the problen of the actual occurrence of $N$-methylhistanine and $N, N$ dimethylhistamine in the sponge Geodesia gigas (6) and in human urine (7), it is certain that the two above imidazo-e-pyridine derivatives were hitherto completely unknown in nature.

The skin of Leptodactylus pentadactyus labyrinthicus offers the nost complete sample card of inidazolealkylanimes one can imagine and an unique opportunity for the understanding of the biosynthetic correlations existing among the different compounds.

It has keen known for a long time and has recently been confirmed in this Labora- 
tory that amphibian skin may possess potent $N$-methyltransferase activities (5)$\mathrm{HT} \rightarrow N$-methyl-5-H'T $\rightarrow$ bufotenine $\rightarrow$ bufotenidine; $p$-tyramine $\rightarrow$ candicine; $m$-tyramine $\rightarrow$ leptodactyline).

For this reason, in our attempt to identify the many imidazole spots developed on the Leptodactylus chromatograms by the Pauly reagent we immediately directed our attention to the $N$-methylated derivatives of histamine, especially since eluates of some spots proved to be furnished with potent biological activity.

Two of the spots could easily be identified by paper chromatography and bioassay with $N$-methylhistamine and $N, N$-dimethylhistamine, respectively. So far, the search for the trimethylammonium derivative of histamine has been unsuccessful.

The discovery by Ackermann $(8,9)$ of spinacine in the liver of the shark Acanthias vulgaris and in the tissues of the crab (rango vulgaris suggested the possibility that one or more of our chromatographic spots could be made up of imidazo-c-pyridine derivatives, i.e., of $N$-methylated histamines with the lateral chain linked through one $N$-methyl group to the carbon atom 5 of the inidazole nucleus.

We could not find any evidence for the occurrence of spinacine in the Leptodactylus extracts, but it soon appeared that two imidazole compounds of these extracts were indistinguishable from $4,5,6,7$-tetrahydroindidazo [5,4-e] pyridine and 6 -methy $1-4,5$, 6,7-tetrahydroimidazo $[5,4-c]$ pyridine, respectively. lor the new inidazo-c-pyridine derivatives we suggest the names of spinaceamine and 6-methylspinaceamine, respectively, to denote their strict relationship with Ackermann's spinacine.

So far, attempts to decarboxylate spinacine by homogenates of mammalian and frog tissues (Hanson, personal communication) and to trace decarboxylation derivatives of spinacine in the urine of rats given the amino acid (De Caro, unpublished observations) have been unsuccessful. This, joined to the apparent lack of spinacine in Leptodartylus extracts makes a direct derivation of spinaceamine from spinacine highly questionable.

Thus, the biosynthetic pathway most likely to connect the inidazole derivatives herein described is that represented schematically on opposite page.

Amphibian skin is the only localization of the new histamine compounds discovered so far, but it is highly probable that systematic research will trace them in a number of other vertebrate and invertebrate tissues. To begin with, it would be advisable to check according to the extremely simple methods deseribed in this paper the few natural examples of $N$-methylhistanine and $N, N$-dimethylhistamine already described in the literature.

Gaddum (10) has recently suggested that there is reason to believe that methylation of the amino group is the most important mechanism by which histamine is inactivated in the body. The present data offer strong support to this view.

The possible importance of results obtained in this and similar studies as a basis for a biochemical taxonomy of amphibians will be discussed in detail elsewhere.

Note added in proof. Since this paper was submitted for publication further progress has been made in the study of the imidazolealkylamines of the Leptodactylus pentadactylus labyrinthicus skin:

(1) Spot 1 of the chromatograms could be identified with $N$-acetylhistanine, a histamine metabolite so far found only in urine.

(2) Comparative experiments on the yield of inidazolealkylamines following extraction of a pool of minced dry skins of Leptodactylus pentadactylus labyrinthicus (December, 196:3) with $70 \%$ acetone and $80 \%$ methanol, respectively, gave the following results:

Histamine

$\therefore$-Methylhistamine

$\therefore, N$-Dimethylhistamine

Spinaceamine

(j-Methylspinaceamine

5-Hydroxytryptamine

$\begin{array}{cc}70 \% \text { acetone } & 80 \% \text { methanol } \\ (\mu \text { g. } / \text { g. dry } & \text { tissue }) \\ 50 & 120 \\ 200 & 480 \\ 80 & 140 \\ 14 & 6 \\ 75 & 30 \\ 1500 & 1400\end{array}$

It clearly appears that, whereas extraction of histamine, $N$-methylhistamine, and $N, N$ dimethyhistamine is more complete with methanol, that of spinaceamine and 6-methylspinaceamine is more complete with 
<smiles>N[C@@H](Cc1c[nH]cn1)C(=O)O</smiles>

Histidine<smiles>NCCc1c[nH]cn1</smiles>

Histamine<smiles>CCCC[Tl]</smiles><smiles>CNCc1c[nH]cn1</smiles>

$N^{\prime}$-Methylhistamine<smiles>[3H]CCC</smiles><smiles>CN(C)CCc1c[nH]cn1</smiles>

$N^{t}, N^{\prime}$-Dimethylhistamine

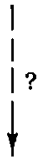

Ammonium quaternary base

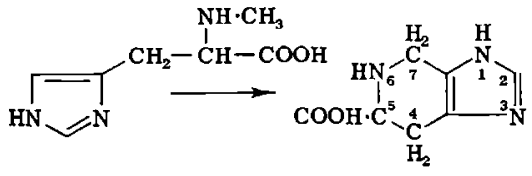

$N^{\prime}$-Methylhistidine

Spinacine<smiles>c1nc2c([nH]1)CNCC2</smiles>

Spinaceamine<smiles>CN1CCc2nc[nH]c2C1</smiles>

6-Methylspinaceamine acetone. Extraction of 5 -HT is the same with the two solvents.

\section{REFERENCES}

1. Erspamer, V., Arch. Biochem. Biophys. 82, 431 (1959).

2. Erspamer, V., Vitali, T., Roseghini, M., AND Cei, J. M., Experientia 19, 346 (1963).

3. Porath, J., Biochim. Biophys. Acta 39, 193 (1960).

4. Vitali, T., and Bertaccini, G., Gazzella Chim. Ital., in press.
5. ACkermann, D., and Skraup, S., Z. Physiol. Chem. 284, 129 (1949).

6. Ackermann, D., Holtz, F., and Reinwein, H., Z. Biol. 82, 278 (1924).

7. Kapeller-Adler, R., ANd Iggo, B., Biochim. Biophys. Acta 25, 394 (1957).

8. Ackermann, D., Z. Physiol. Chem. 328, 275 (1962).

9. Ackermann, D., and Müller, E., Z. Physiol. Chem. 268, 277 (1941).

10. Gaddum, J. H., Proc. Intern. Union Physiol. Sci. 1, 849 (1962). 
i 